\title{
MAGNETIC TREATMENT OF IRRIGATION WATER FOR IMPROVING VEGETATIVE GROWTH, FRESH AND DRY YIELD OF BEAN (PHASEOLUS VULGARIS L.) GROWN UNDER PLASTIC HOUSE
}

\author{
KHATTAB, ENTSAR K.A., MONA M. ABDEL-WANES,
} AMAL Z. HEGAZI and A.E. ARAFA

Horticulture Research Institute, ARC, Giza, Egypt.

Corresponding authors: mana_arc@yahoo.com

(Manuscript received 21 September 2014)

\begin{abstract}
Using magnetic water is an important environmental factor for agriculture in irrigation systems specially drip irrigation. However, its impact on plant growth is not well studied under normal conditions. Two field experiments were conducted during 2011/2012 and 2012/2013 seasons in a plastic house at Horticulture Research Institute, Kaha station, Kalyobia governorate, Egypt to study the impact of magnetized water on growth, yield and some chemical constituents of two bean (Phaseolus vulgaris L.) cultivars Goya and Hama. Results showed significant positive effects of magnetic water on quantity and quality of the studied parameters such as germination \%, leaf area/ plant, early and total green pods and seeds weight/ plant. Irrigation with magnetic water gave more vigorous plants. Most studied traits of bean such as vegetative growth (plant height, No. of leaves/ plant, fresh \& dry weight/ plant and leaf area/ plant), seed yield and NPK contents of leaves showed significant increase when magnetic water was used. The response of the two cultivars to the magnetic water has similar trend. However, "Goya" cv gave higher values of vegetative growth measurements as well early and total green pod yield/ plant and seed yield (seed weight/ plant and weight of 100 seeds). The enhancement of these studied characters may be due to that the irrigation with magnetized water make plants absorb more nutrients from soil. Increasing of soil nutrients enhancement photosynthesizes property of plants. This experiment was carried out in order to highlight the efficiency use of magnetic water on bean yield and its components.
\end{abstract}

Key words: Beans, Phaseolus vulgaris, magnetic water, plastic house.

\section{INTRODUCTION}

The technology of magnetic water has widely studied and adopted in field of agriculture in many countries. In spite of its importance, it is not yet explored in Egypt and available review on the application of magnetize water in agriculture is still limited (Hozayn et al. 2011; Hozayn and Qados 2010 a,b). Magnetized water is obtained by 
passing water through a strong permanent magnet installed in or on a feed pipeline (Mostafazadeh-Fard et al 2011). Some information that are available in the literature explain that the magnetic treatment of water modify its structural array, which increases the intercellular movement. Such process may result in greater nutrient uptake increasing the physiological processes related to the crop production (Scaloppi 2008).

The improvement of growth, yield, yield components and chemical constituents of lentil and chickpea by using magnetized water had been found by Hozayn and Qados (2010a) and Qados and Hozayn (2010). They showed that, in pot experiments carried out in a greenhouse in Egypt, irrigating chickpea and lentil plants with magnetized water significantly improved the most above mentioned parameters compared with tap water. The percentage of increment reached to $21.75,18.18$, and 15.05 for plant height, fresh weight per plant and dry weight per plant, respectively for lentil while the percentage of increase in seed, straw and biological yield per plant were 39.64, 41.03 and $39.85 \%$, respectively, for chickpea.

Sadeghipour and Aghaei (2013) studied the effect of irrigation with magnetized water on cowpea. They detected an increase in leaf, stem and root fresh and dry weights, leaf area as well as total biomass as compared to those values obtained by using ordinary water. They also stated that, the stimulatory impact of magnetic water may be ascribed to the increasing of root growth and stomatal conductance which intern increase absorption and assimilation of nutrients.

In other trials in an open field, Al-Qaesi (2009) found that Magnetized water gave taller and heavier plants, increased total yield and the content of $P$ in watermelon plant. Similarly, the best significant vegetative growth of tomato was obtained by magnetized water, which gave the highest number of shoots (30.23) compared with normal water (Abou El-Yazied et al. 2012).

In this investigation, we selected bean as a module plant to highlight the positive effects of magnetized treated water. Bean is the most important grain legume for human consumption. It provides an inexpensive food rich in macronutrients such as proteins and starch, important micronutrients such as iron, and also a number of other stored bioactive compounds endowed with positive health implications through their antioxidant, anti-tumour or phyto-oestrogenic activity (Doria et al. 2012).

The current research was carried out with the objectives of evaluation and clarifying the influence of magnetic treated water for bean cultivation (green pod and seed yield) so that it can be used in large scales. 


\section{MATERIALS AND METHODS}

Two main experiments were carried out in the two successive winter seasons 20112012 and 2012-2013. The first (experiment I) was a pot experiment and was conducted to study germination percentage and germination rate for two bean (Phaseolus vulgaris L.) cultivars, namely, Goya and Hama under normal and magnetic water irrigation.

Each treatment (cultivar and water type) consists of 10 plastic pots $30 \mathrm{~cm}$ diameter under plastic house condition. Growing media was taken from of plastic house soil (clayey). Each pot contains 10 seeds. The second (experiment II), the same two cultivars were cultivated under the same plastic house of an area $360 \mathrm{~m}^{2}(40 \mathrm{~m}$ long $\mathrm{x}$ $9 \mathrm{~m}$ width $\times 3 \mathrm{~m}$ height) at Kaha Research Station, Horticulture Res. Inst., Agriculture Research Center, Ministry of Agriculture, Egypt. The soil texture of the experimental field was loamy clay. Plants under plastic house were irrigated by drip irrigation and fertilized according to the recommendations of the Ministry of Agriculture. The experiment design was split plot with three replicates, the two cultivars (Goya and Hama) were arranged in the main plots and irrigation water types treatments (magnetized and normal) were distributed in the sup-plots. In this experiment, plants were drip irrigated either by normal water or by magnetically treated water. Magnetized water was obtained by passing water through a permanent magnet installed on a feed pipeline (magnetic water treatment system. soften, purify, clean merchant sku: mwts -010 which has a pulling force of over $69 \mathrm{lbs}$ ).

Seeds of bean cultivars Goya and Hama were sown in the first week of November in both seasons. The area of each experimental plot was $10 \mathrm{~m}^{2}$ consisted of one row (10 $\mathrm{m}$ length with $1 \mathrm{~m}$ width). Seeds were planted on the two sides of each ridge at 50 $\mathrm{cm}$ apart.

Other cultural practices as fertilizing, harrowing and irrigation were carried out as commonly practiced for the conventional bean planting recommended by ministry of Agriculture.

The water analysis of the tow samples; normal or magnetically treated are represented in Table 1 as follows: 
Table 1. Water analysis for magnetic treated water (mag) and normal water (normal)

\begin{tabular}{|c|c|c|c|c|c|c|c|c|c|c|c|c|c|c|}
\hline \multirow[t]{2}{*}{ Sample } & \multirow[t]{2}{*}{$\mathrm{pH}$} & \multirow[t]{2}{*}{$\begin{array}{l}\text { E.C. } \\
\mathrm{dS} / \mathrm{m}\end{array}$} & \multirow[t]{2}{*}{$\begin{array}{l}\text { TDS } \\
\text { ppm }\end{array}$} & \multicolumn{4}{|c|}{$\begin{array}{c}\text { Soluble cations } \\
\text { meq/ L }\end{array}$} & \multicolumn{4}{|c|}{$\begin{array}{c}\text { Soluble anions } \\
\text { meq/ L }\end{array}$} & \multirow[t]{2}{*}{ S.A.R. } & \multirow[t]{2}{*}{ R.S.C. } & \multirow[t]{2}{*}{$\begin{array}{c}\text { S.S.P. } \\
\%\end{array}$} \\
\hline & & & & $\mathrm{Ca}^{+}$ & $\mathrm{Mg}^{+}$ & $\mathrm{Na}^{+}$ & $\mathrm{K}^{+}$ & $\mathrm{CO}_{3}^{-}$ & $\mathrm{HCO}_{3}^{-}$ & $\mathrm{Cl}^{-}$ & $\mathrm{SO}_{4}^{-}$ & & & \\
\hline Normal & 7.9 & 1.2 & 768 & 3.2 & 5 & 4.73 & 0.45 & - & 5.6 & 3.75 & 4.03 & 2.34 & -2.6 & 35.4 \\
\hline Mag & 7.8 & 1.1 & 723 & 2.6 & 5.8 & 4.6 & 0.40 & - & 3.1 & 3.5 & 6.35 & 2.24 & -4.8 & 34.2 \\
\hline
\end{tabular}

S.A.R. = Sodium Absorption Ratio, R.S.C. = Residual Sodium Carbonate, S.S.P. = Soluble sodium Percentage, TDS $=$ Total Dissolved Salts

\section{Data recorded}

\section{Experiment I}

\section{A. Germination percentage and mean emergence time}

Pots were checked daily and newly emerged shoots were recorded until this process was completed. Seedlings were assumed as have emerged when the plants became free above the soil surface.

Germination percentage was calculated as the following:

$$
\text { Germination percentage }=\frac{\text { Number of germinated seeds }}{\text { Number of total seeds }} \times 100
$$

Mean emergence time was calculated according to the following equation

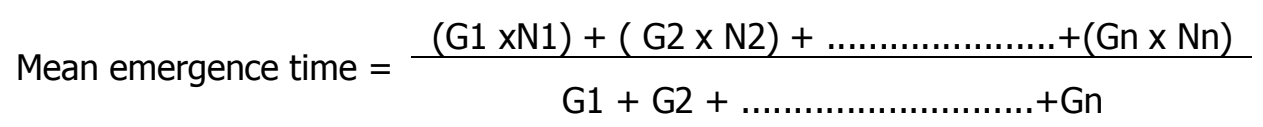

Where: $\mathrm{G}=$ Number of germinated seeds in certain day, $\mathrm{N}=$ Number of this certain day.

\section{Experiment II}

\section{B. Vegetative growth}

Three plant samples were randomly chosen from each experimental treatment after 75 days (end of flowering stage and beginning of fruit set) from sowing. Each plant sample was dissected into different organs (root, stem, leaves and fruits). The following growth criteria were recorded: plant height $(\mathrm{cm})$, number of leaves /plant, leaf area/plant $\left(\mathrm{cm}^{2}\right)$, fresh weight/ plant $(\mathrm{g})$ and dry weight/ plant $(\mathrm{g})$. Total plant leaves area was measured by cutting out leaf discs from leaves using cork borer then dried in an oven at $75 \mathrm{C}^{\circ}$ for $48 \mathrm{~h}$. Based on the known dry weigh of known surface area of leaves; i.e., leaf discs and total dry weight of leaves/ plant with known area and weight of leaf discs; leaf area was calculated. Flowering was determined as the number of days from sowing till flowering $50 \%$ of plants of each experimental plot. 


\section{Green pod yield and its quality}

Yield and its components were determined as follows: early yield (the fruit yield of the first three harvests) and the total yield throughout the entire harvesting season. The first harvest was taken after 80 days from planting then regular harvest each seven days. Fruit measurements were: pod fresh weight $(\mathrm{g})$, pod diameter $(\mathrm{cm})$, pod length (cm) and dry mater \% of pods.

\section{Chemical analysis}

Mineral concentrations were determined in plant leaves. Total nitrogen was determined using micro-Keldahl apparatus, phosphorus was estimated calorimetrically and potassium was determined by using flame-photometrically (A.O.A.C 2000).

\section{E. Seed yield and its components and seed testing parameters}

Ten plants were left without pod harvest until seed stage. Samples of plants from each treatment were used to record the following characters:

pod length $(\mathrm{cm})$, number of pods/plant, number of seeds/pod, pods weight/plant $(\mathrm{g})$, seeds weight/plant $(\mathrm{g})$, and total seed weight $(\mathrm{g}) / \mathrm{m}^{2}$.

\section{Statistical analysis}

The experimental design was split plot and the statistical analysis was carried out according to the method described by Snedecor and Cochran (1980). Data were subjected to the proper analysis by using the Duncan's Multiple Range Test at 5\% (Duncan, 1955).

\section{RESULTS AND DISCUSSION}

\section{Experiment I (pot experiment)}

\section{Germination percentage and mean emergence time}

Data represented in Table 2 showed that Goya recorded significant increase in both seasons in germination \% and mean emergence time (Goya took fewer days for complete germination). Using magnetic water showed significant improvement in both season in germination \% as well mean emergence time. Interaction between cultivars and irrigation water demonstrated that Goya recorded better results with magnetic water.

Similar results were reported by Selim et al (2013) as they found that magnetic field treated water increased seed germination percentage and seedling vigor index of tomato and pea. In another trial by Grewal and Maheshwari (2011) on pea and chickpea, the results showed that magnetic treated water led to a significant increase $(P<0.05)$ in emergence rate index. These findings are in agreement with the results of this study where the germination rate decreases with using magnetic water. 


\section{Experiment II}

\section{A. Vegetative growth}

Data presented in Table 3 showed that Goya gave greater records than Hama in most growth attributes. These improvements were significant in both seasons with number of leaves /plant and fresh and dry weight/ plant. For plant height, Goya gave significant increase in the second season only while this increase didn't reach the significant level in the first season. There is no significant difference between the two cultivars in the leave area/ plant. Using magnetic water showed significant increase in both seasons for all growth criteria illustrated except plant height in the first season, the increase wasn't significant. The interaction between cultivars and irrigation water showed that magnetically treated water gave better significant results for most growth criteria in both seasons and the highest values were obtained by Goya. In the second season, there was no significant difference between magnetic and non magnetic water with Goya variety and for leaf area/ plant. Hama recorded the highest value with magnetic water.

In another trial on tomato and pea, Selim et al (2013) found that magnetic field treated water increased seed germination percentage and seedling vigor index. Magnetic field treated water increased also plant height and leaf area per plant. Biochemical analysis of the plant leaves irrigated by magnetic water clarified some changes associated with the modifications in the membrane integrity of the plant leaves and the concentrations of some endogenous hormones in the plant shoots. In addition Nasher (2008) reported an increase in chick pea plants length which was irrigated with magnetized water compared with plant irrigated with tap water. Plants irrigated with magnetized water acquire more nutrients from soil.

\section{B. Green pod yield and its quality}

\section{Flowering and green pod yield}

In the two seasons, there was no significant deference between the two cultivars in total yield/ plant and yield/ $\mathrm{m}^{2}$ but Goya gave a significant improvement in the flowering and early yield / plant (Table 4). Also, magnetic water had positive significant effect in the tow seasons on early and total fresh yield/ plant as well yield/ $\mathrm{m}^{2}$. As regard to flowering, it is clear that magnetic water gave the best results (fewer days) in both seasons significantly in second only. Interaction between cultivars and water showed that Goya cultivar gave the best results with magnetic water; this improvement was significant in some growth criteria and was no significant in others. Increase yield by irrigation with magnetic water was noticed by many authors. Abou El-Yazied et al (2012) reported an increase in total yield of tomato. Hozayn et al (2011) 
detected similar increase in chick-pea and lentil. Irrigation of cabbage with magnetic treated water led to a significant increase in marketable yield and head quality was positively affected (Bogoescu, 2000). In addition, tomato yield improved significantly by as much as $46 \%$ by magnetic water (Peilai et al 2004 ).

The yield of beans grown in a greenhouse irrigated by magnetized water increased by $28.9 \%$. This yield increase may be due to that the magnetic treatment of water modifies its structural array, which increases the intercellular movement. Such process may result in greater nutrient uptake increasing the physiological processes related to the crop production (Scaloppi, 2008).

\section{Pod quality}

There is no significant difference between most pods quality attributes for the two cultivars of bean in both seasons (Table 5). Pod length of Hama recorded significant increase in the first season. In the second season, there was significant increase in pod fresh weight recorded by Hama and in dry matter pod percentage recorded by Goya. Application of the magnetic water had the highest significant values for pod length and pod diameter in the first season and for pod fresh weight and dry matter in the second season. Interaction between cultivars and irrigation water indicated that magnetic water irrigation gave the best results for pod length, diameter and fresh weight with Hama and for dry matter with Goya. Our results represented in Table 3 showed that the increase in pod yield came from increase in pod length, diameter and weight. Similar result was reported by Hozayn and Qados (2010a) on chickpea.

\section{Chemical constitutes}

Data represented in Table 6 indicated that Hama recorded the best results for nitrogen and potassium contents but Goya was superior in phosphorus content. In Hama, the high level of nitrogen was significant in the second season only while of potassium it was significant in both seasons. In Goya, its high level of phosphorous content wasn't significant in both seasons. Magnetically treated water recorded significant increase in NPK in first season only, while in second season this increase wasn't significant. Interaction between water type and cultivars clarified that, with magnetic water: Hama recorded significant increase for nitrogen and potassium in first season only, while Goya showed significant increment in phosphorus in second season.

These results were proved by Grewal and Maheshwari (2011) who found that magnetically treated water led to a significant increase $(P<0.05)$ in contents of $N, K$, $\mathrm{Ca}, \mathrm{Mg}, \mathrm{S}, \mathrm{Na}, \mathrm{Zn}, \mathrm{Fe}$ and $\mathrm{Mn}$ in both seedling of snow pea and chickpea compared to control. Similar finding was recorded by El Sayed (2014) who stated that magnetic 
water treatment could be used to enhance inorganic minerals $\left(\mathrm{K}^{+}, \mathrm{Na}^{+}, \mathrm{Ca}^{+2}\right.$ and $\left.\mathrm{P}^{+3}\right)$ contents in all parts of broad bean plant under greenhouse condition.

In addition use of magnetic treated water for cabbage irrigation improved some of the biochemical indicators such as: soluble dry matter (7.5\%), titratable acidity $(0.33 \%)$, soluble sugars (3.3\%), ascorbic acid $(33.3 \mathrm{mg} / 100 \mathrm{~g})$, chlorophyll pigments (13.86 $\mathrm{mg} / 100 \mathrm{~g}$ ) and mineral salts content (1.14\%) Bogoescu (2000)

\section{Seed yield and seed quality}

The highest mean values of seed yield and seed quality characters of bean were observed with Goya (Table 7). This increment was non significant for number of seeds/ pod and germination rate while it was significant in other traits, viz., number of pods/ plant, seed weight/ plant, seed weight / $\mathrm{m}^{2}$, weight of 100 seed and germination percentage. Magnetic water had positive significant effect in both seasons on most studied traits. Also, it is clear from the results that magnetic water had stimulatory significant effect on the mean germination time, i.e., seeds produced from plant took fewer days to complete germination. Interaction between cultivars and irrigation water demonstrated that, Goya recorded the best results with magnetically treated water; significantly with in some criteria and non significantly in others.

In this connection, Maheshwari and Grewal (2009) reported that the use of magnetically treated irrigation water (as to soil properties after plant harvest) has some beneficial effects as it reduced soil pH but increased soil EC and available P in celery and snow pea.

Hozayn et al. (2011) reported that the magnetized water treatment increased seed yield/ plant reached to $26.92 \%$ for lentil and $46.62 \%$ for check-pea, compared with plants irrigated with tap water under greenhouse condition. Also, Maheshwari and Grewal (2009) found that, for snow peas, there were 7.8\%, 5.9\% and 6.0\% increases in pod yield with magnetically treated potable water, recycled water and $1000 \mathrm{ppm}$ saline water, respectively. However, El Sayed (2014) indicated that, irrigating broad bean with magnetic water induced positive significant effect on all seed parameters and seed yield components such as: legumes no. /plant, legumes wt. /plant, seeds no. / plant, 100 seeds weight and seeds yield /plant. 


\section{CONCLUSION}

The results clarified the high- efficiency used of magnetically treated water in plastic house cultivation of bean (Phaseolus vulgaris L.). Our findings demonstrated the same response of the two cultivars under investigation. Most growth attributes of the two cultivars stimulated positively and improved significantly in response to irrigation with magnetically treated water.

Finally we emphasized that the technique of treated water magnetically in agricultural fields could be a promising technique for agricultural improvement. This technique could be applied efficiency for more vegetable crops.

Table 2. Effect of irrigation with normal tap water (normal) and magnetic water (mag) on germination percentage and mean emergence time of bean cultivars (Goya\& Hama) cultivated on pots $30 \mathrm{~cm}$ diameter under plastic house in winter seasons of 2011-2012 and 2012-2013.

\begin{tabular}{|c|c|c|c|c|c|c|}
\hline Characters & \multicolumn{3}{|c|}{ Germination \% } & \multicolumn{3}{|c|}{ Mean emergence time } \\
\hline \multicolumn{7}{|c|}{ First season } \\
\hline Cultivar & Goya & Hama & Mean & Goya & Hama & Mean \\
\hline \multicolumn{7}{|l|}{ Water type } \\
\hline mag & $93.3 \mathrm{a}$ & $87.5 a b$ & $90.40 \mathrm{~A}$ & $7.00 \mathrm{~b}$ & $7.56 a b$ & $7.28 \mathrm{~B}$ \\
\hline normal & $91.7 a b$ & $75.0 \mathrm{~b}$ & $83.35 \mathrm{~B}$ & $7.23 \mathrm{~b}$ & $8.25 \mathrm{a}$ & $7.74 \mathrm{~A}$ \\
\hline Mean & $92.5 \mathrm{~A}$ & $81.25 \mathrm{~B}$ & & $7.12 \mathrm{~B}$ & $7.91 \mathrm{~A}$ & \\
\hline \multicolumn{7}{|c|}{ Second season } \\
\hline Cultivar & Goya & Hama & Mean & Goya & Hama & Mean \\
\hline \multicolumn{7}{|l|}{ Water type } \\
\hline mag & $88.3 \mathrm{a}$ & $82.5 \mathrm{~b}$ & $85.4 \mathrm{~A}$ & $7.70 \mathrm{~b}$ & $8.26 a b$ & $7.98 \mathrm{~B}$ \\
\hline normal & $87.3 \mathrm{a}$ & $70.0 \mathrm{c}$ & $78.65 B$ & $7.93 b$ & $8.95 \mathrm{a}$ & $8.44 \mathrm{~A}$ \\
\hline Mean & $87.8 \mathrm{~A}$ & $76.25 \mathrm{~B}$ & & $7.82 \mathrm{~B}$ & $8.61 \mathrm{~A}$ & \\
\hline
\end{tabular}

Values followed by the same letter are not significantly different, using Duncan's multiple range test at $5 \%$ level. 
Table 3. Effect of irrigation with normal tap water (normal) and magnetic water (mag) on vegetative growth of bean cultivars (Goya\& Hama) grown under plastic house in winter seasons of 2011-2012 and 2012-2013.

\begin{tabular}{|c|c|c|c|c|c|c|c|c|c|c|c|c|c|c|c|}
\hline \multirow{3}{*}{$\begin{array}{l}\text { Characters } \\
\text { Treatments } \\
\text { Cultivar } \\
\end{array}$} & \multicolumn{3}{|c|}{ Plant length } & \multicolumn{3}{|c|}{ No. of leaves/ plant } & \multicolumn{3}{|c|}{ Fresh weight/ plant (g) } & \multicolumn{3}{|c|}{ Dry weight/ plant (g) } & \multicolumn{3}{|c|}{ Leaf area/ plant $\left(\mathrm{m}^{2}\right)$} \\
\hline & \multicolumn{15}{|c|}{ First season } \\
\hline & Goya & Hama & Mean & Goya & Hama & Mean & Goya & Hama & Mean & Goya & Hama & Mean & Goya & Hama & Mean \\
\hline \multicolumn{16}{|l|}{ Watertype } \\
\hline mag & $364 a$ & 276 b & $320.0 \mathrm{~A}$ & $136 \mathrm{a}$ & $75 \mathrm{c}$ & $105.5 \mathrm{~A}$ & $904.8 \mathrm{a}$ & $542.5 \mathrm{bc}$ & 723.7A & $148.9 \mathrm{a}$ & $87.6 \mathrm{bc}$ & $118.3 \mathrm{~A}$ & $1.115 \mathrm{a}$ & $0.974 a b$ & $1.045 \mathrm{~A}$ \\
\hline normal & $329 a b$ & $306 a b$ & $317.5 \mathrm{~A}$ & $104 \mathrm{~b}$ & $73 \mathrm{c}$ & $88.5 \mathrm{~B}$ & $657.4 \mathrm{~b}$ & $435.0 \mathrm{c}$ & $546.2 B$ & $104.1 \mathrm{~b}$ & $73.0 \mathrm{c}$ & $88.55 \mathrm{~B}$ & $0.766 \mathrm{~b}$ & $0.751 \mathrm{~b}$ & $0.759 \mathrm{~B}$ \\
\hline Mean & $346.5 \mathrm{~A}$ & $291 \mathrm{~A}$ & & $120 \mathrm{~A}$ & $74 \mathrm{~B}$ & & $781.1 \mathrm{~A}$ & $488.8 \mathrm{~B}$ & & $126.5 \mathrm{~A}$ & $80.3 \mathrm{~B}$ & & $0.941 \mathrm{~A}$ & $0.863 \mathrm{~A}$ & \\
\hline & \multicolumn{15}{|c|}{ Second season } \\
\hline Cultivar & Goya & Hama & Mean & Goya & Hama & Mean & Goya & Hama & Mean & Goya & Hama & Mean & Goya & Hama & Mean \\
\hline \multicolumn{16}{|l|}{ Watertype } \\
\hline mag & 305 a & $259 \mathrm{c}$ & $282 \mathrm{~A}$ & $100 \mathrm{a}$ & $67 c$ & $83.5 \mathrm{~A}$ & $715.4 \mathrm{a}$ & $425.1 \mathrm{~b}$ & $570.3 \mathrm{~A}$ & $115.2 \mathrm{a}$ & $69.1 \mathrm{~b}$ & $92.2 \mathrm{~A}$ & $0.735 \mathrm{ab}$ & $0.758 \mathrm{a}$ & $0.747 \mathrm{~A}$ \\
\hline normal & $279 \mathrm{~b}$ & $269 \mathrm{bc}$ & $274 B$ & $79 \mathrm{~b}$ & $59 \mathrm{~d}$ & $69 \mathrm{~B}$ & $469.6 \mathrm{~b}$ & $318.8 \mathrm{c}$ & $394.2 B$ & $73.4 \mathrm{~b}$ & $52.4 \mathrm{c}$ & $62.9 \mathrm{~B}$ & $0.475 \mathrm{c}$ & $0.593 \mathrm{bc}$ & $0.534 \mathrm{~B}$ \\
\hline Mean & $292 \mathrm{~A}$ & $264 B$ & & $89.5 \mathrm{~A}$ & $63 B$ & & $592.5 \mathrm{~A}$ & $372 B$ & & $94.3 \mathrm{~A}$ & $60.8 \mathrm{~B}$ & & $0.605 \mathrm{~A}$ & $0.676 \mathrm{~A}$ & \\
\hline
\end{tabular}

Values followed by the same letter are not significantly different, using Duncan's multiple range test at $5 \%$ level. 
Table 4. Effect of irrigation with normal tap water (normal) and magnetic water (mag) on flowering and green pod yield of bean cultivars (Goya\& Hama) grown under plastic house in winter seasons of 2011-2012 and 2012-2013.

\begin{tabular}{|c|c|c|c|c|c|c|c|c|c|c|c|c|}
\hline \multirow{3}{*}{$\begin{array}{l}\text { Characters } \\
\text { Treatments } \\
\text { Cultivar }\end{array}$} & \multicolumn{3}{|c|}{ Flowering (day) } & \multicolumn{3}{|c|}{ Early yield/ plant (g) } & \multicolumn{3}{|c|}{ Total yield/plant (g) } & \multicolumn{3}{|c|}{ Yield /m² (g) } \\
\hline & \multicolumn{12}{|c|}{ First season } \\
\hline & Goya & Hama & Mean & Goya & Hama & Mean & Goya & Hama & Mean & Goya & Hama & Mean \\
\hline \multicolumn{13}{|l|}{ Water type } \\
\hline mag & $55.7 \mathrm{~b}$ & $68.3 \mathrm{a}$ & $62.0 \mathrm{~A}$ & 395 a & $211 \mathrm{~b}$ & $303 \mathrm{~A}$ & 613 a & $459 \mathrm{ab}$ & $536 \mathrm{~A}$ & 7356 a & $5508 \mathrm{ab}$ & $6432 \mathrm{~A}$ \\
\hline normal & $60.7 \mathrm{~b}$ & $73.7 \mathrm{a}$ & $67.2 \mathrm{~A}$ & $242 b$ & $140 \mathrm{c}$ & 191B & 475 a & $305 b$ & 390B & $5700 \mathrm{a}$ & $3660 \mathrm{~b}$ & $4680 \mathrm{~B}$ \\
\hline \multirow[t]{2}{*}{ Mean } & $58.2 B$ & $71.0 \mathrm{~A}$ & & $318.5 \mathrm{~A}$ & $175.5 B$ & & $544 \mathrm{~A}$ & $382 \mathrm{~A}$ & & $6528 \mathrm{~A}$ & $4584 \mathrm{~A}$ & \\
\hline & \multicolumn{12}{|c|}{ second season } \\
\hline Cultivar & Goya & Hama & Mean & Goya & Hama & Mean & Goya & Hama & Mean & Goya & Hama & Mean \\
\hline \multicolumn{13}{|l|}{ Water type } \\
\hline mag & $60.1 \mathrm{~d}$ & $67.8 b$ & $63.95 \mathrm{~B}$ & 300.5 a & $163.7 \mathrm{~b}$ & $232.1 \mathrm{~A}$ & $467.41 \mathrm{a}$ & $360.4 a b$ & $413.91 \mathrm{~A}$ & 5609 a & $4325 a b$ & $4967 \mathrm{~A}$ \\
\hline normal & $65.4 \mathrm{c}$ & $74.0 \mathrm{a}$ & $69.7 \mathrm{~A}$ & $171.6 \mathrm{~b}$ & $99.8 \mathrm{c}$ & 135.7B & $334.1 \mathrm{ab}$ & $217.9 \mathrm{~b}$ & 276.0 B & $4009 a b$ & $2615 b$ & 3327 B \\
\hline Mean & $62.75 \mathrm{~B}$ & $70.9 \mathrm{~A}$ & & $236.05 \mathrm{~A}$ & 131.75B & & $400.76 \mathrm{~A}$ & $289.15 A$ & & $4809 \mathrm{~A}$ & $3470 A$ & \\
\hline
\end{tabular}

Values followed by the same letter are not significantly different, using Duncan's multiple range test at $5 \%$ level. 
Table 5. Effect of irrigation with normal tap water (normal) and magnetic water (mag) on green pod quality of bean cultivars (Goya\& Hama) grown under plastic house in winter seasons of 2011-2012 and 2012-2013.

\begin{tabular}{|c|c|c|c|c|c|c|c|c|c|c|c|c|}
\hline \multirow{2}{*}{\begin{tabular}{|l} 
Characters \\
Treatments
\end{tabular}} & \multicolumn{3}{|c|}{ Pod length $(\mathrm{cm})$} & \multicolumn{3}{|c|}{ Pod diameter $(\mathrm{cm})$} & \multicolumn{3}{|c|}{ Pod fresh weight $(\mathrm{g})$} & \multicolumn{3}{|c|}{ Dry mater of pods (\%) } \\
\hline & \multicolumn{12}{|c|}{ First season } \\
\hline Cultivar & Goya & Hama & Mean & Goya & Hama & Mean & Goya & Hama & Mean & Goya & Hama & Mean \\
\hline \multicolumn{13}{|l|}{ Water type } \\
\hline mag & $14.7 \mathrm{bc}$ & $16.0 \mathrm{a}$ & $15.35 \mathrm{~A}$ & 0.75 bc & $0.81 \mathrm{a}$ & $0.780 \mathrm{~A}$ & $6.95 a b$ & $7.37 \mathrm{a}$ & $7.16 \mathrm{~A}$ & $12.33 \mathrm{a}$ & $12.11 \mathrm{a}$ & $12.22 \mathrm{~A}$ \\
\hline normal & $13.8 \mathrm{C}$ & $15.0 a b$ & $14.4 \mathrm{~B}$ & $0.74 \mathrm{c}$ & $0.77 \mathrm{~b}$ & $0.755 B$ & $6.62 b$ & $7.35 \mathrm{a}$ & $6.99 \mathrm{~A}$ & $12.23 \mathrm{a}$ & $11.87 \mathrm{a}$ & $12.05 \mathrm{~A}$ \\
\hline Mean & $14.25 B$ & $15.5 \mathrm{~A}$ & & $0.745 \mathrm{~A}$ & $0.790 \mathrm{~A}$ & & $6.79 \mathrm{~A}$ & $7.36 \mathrm{~A}$ & & $12.28 \mathrm{~A}$ & $11.99 \mathrm{~A}$ & \\
\hline & \multicolumn{12}{|c|}{ second season } \\
\hline Cultivar & Goya & Hama & Mean & Goya & Hama & Mean & Goya & Hama & Mean & Goya & Hama & Mean \\
\hline \multicolumn{13}{|l|}{ Water type } \\
\hline mag & $13.7 a b$ & $14.6 \mathrm{a}$ & $14.15 \mathrm{~A}$ & $0.68 \mathrm{~b}$ & $0.75 \mathrm{a}$ & $0.715 \mathrm{~A}$ & $6.43 \mathrm{~b}$ & $6.84 a$ & $6.635 \mathrm{~A}$ & $11.90 \mathrm{a}$ & $11.13 \mathrm{c}$ & $11.515 \mathrm{~A}$ \\
\hline normal & $13.0 \mathrm{~b}$ & $13.7 a b$ & $13.35 \mathrm{~A}$ & $0.72 a b$ & $0.70 a b$ & $0.710 \mathrm{~A}$ & $5.93 \mathrm{c}$ & $6.71 \mathrm{a}$ & $6.320 \mathrm{~B}$ & $11.15 b$ & $11.00 \mathrm{~d}$ & $11.075 \mathrm{~B}$ \\
\hline Mean & $13.35 \mathrm{~A}$ & $14.15 \mathrm{~A}$ & & $0.700 \mathrm{~A}$ & $0.725 \mathrm{~A}$ & & $6.180 \mathrm{~B}$ & $6.775 \mathrm{~A}$ & & $11.525 \mathrm{~A}$ & $11.065 \mathrm{~B}$ & \\
\hline
\end{tabular}

Values followed by the same letter are not significantly different, using Duncan's multiple range test at $5 \%$ level. 
Table 6. Effect of irrigation with normal tap water (normal) and magnetic water (mag) on chemical composition of bean leaves of cultivars (Goya\& Hama) cultivated grown under plastic house in winter seasons of 2011-2012 and 2012-2013.

\begin{tabular}{|c|c|c|c|c|c|c|c|c|c|}
\hline \multirow{2}{*}{\begin{tabular}{|l} 
Characters \\
Treatments \\
\end{tabular}} & \multicolumn{3}{|c|}{$\mathrm{N} \%$} & \multicolumn{3}{|c|}{$\mathrm{P} \%$} & \multicolumn{3}{|c|}{ K \% } \\
\hline & \multicolumn{9}{|c|}{ First season } \\
\hline Cultivar & Goya & Hama & Mean & Goya & Hama & Mean & Goya & Hama & Mean \\
\hline \multicolumn{10}{|l|}{ Water type } \\
\hline mag & $1.68 \mathrm{bc}$ & $1.87 \mathrm{a}$ & $1.775 \mathrm{~A}$ & $0.44 a$ & $0.41 a b$ & $0.425 \mathrm{~A}$ & $1.59 \mathrm{c}$ & $1.87 \mathrm{a}$ & $1.730 \mathrm{~A}$ \\
\hline normal & $1.54 \mathrm{C}$ & $1.71 \mathrm{~b}$ & $1.625 \mathrm{~B}$ & $0.35 b$ & $0.35 b$ & $0.350 \mathrm{~B}$ & $1.54 \mathrm{C}$ & $1.71 \mathrm{~b}$ & $1.625 \mathrm{~B}$ \\
\hline \multirow[t]{2}{*}{ Mean } & $1.61 \mathrm{~A}$ & $1.79 \mathrm{~A}$ & & $0.395 \mathrm{~A}$ & $0.380 \mathrm{~A}$ & & $1.565 \mathrm{~B}$ & $1.790 \mathrm{~A}$ & \\
\hline & \multicolumn{9}{|c|}{ second season } \\
\hline Cultivar & Goya & Hama & Mean & Goya & Hama & Mean & Goya & Hama & Mean \\
\hline \multicolumn{10}{|l|}{ Water type } \\
\hline mag & $1.39 \mathrm{~b}$ & $1.67 \mathrm{a}$ & $1.53 \mathrm{~A}$ & $0.35 \mathrm{a}$ & $0.32 \mathrm{~b}$ & $0.335 \mathrm{~A}$ & $1.36 \mathrm{~b}$ & $1.58 \mathrm{a}$ & $1.47 \mathrm{~A}$ \\
\hline normal & $1.36 \mathrm{~b}$ & $1.58 \mathrm{a}$ & $1.47 \mathrm{~A}$ & $0.28 \mathrm{c}$ & $0.29 \mathrm{c}$ & $0.285 \mathrm{~A}$ & $1.39 \mathrm{~b}$ & $1.67 \mathrm{a}$ & $1.515 \mathrm{~A}$ \\
\hline Mean & $1.375 B$ & $1.625 \mathrm{~A}$ & & $0.315 \mathrm{~A}$ & $0.305 \mathrm{~A}$ & & $1.375 \mathrm{~B}$ & $1.625 \mathrm{~A}$ & \\
\hline
\end{tabular}

Values followed by the same letter are not significantly different, using Duncan's multiple range test at $5 \%$ level. 
Table 7. Effect of irrigation with normal tap water (normal) and magnetic water (mag) on dry seed yield and seed testing of bean cultivars (Goya\& Hama) grown under plastic house in winter seasons of 2011-2012 and 2012-2013.

\begin{tabular}{|c|c|c|c|c|c|c|c|c|c|c|c|c|c|c|c|c|c|c|c|c|c|}
\hline \multirow{3}{*}{\begin{tabular}{|c} 
Characters \\
Treatments
\end{tabular}} & \multicolumn{3}{|c|}{ No. of pods/plant } & \multicolumn{3}{|c|}{ No. of seeds/ pod } & \multicolumn{3}{|c|}{ Seed weight /plant (g) } & \multicolumn{3}{|c|}{ Seed weight $/ \mathrm{m}^{2}(\mathrm{~g})$} & \multicolumn{3}{|c|}{ Weight of 100 seed $(\mathrm{g})$} & \multicolumn{3}{|c|}{ Germination \% } & \multicolumn{3}{|c|}{ Mean germination time } \\
\hline & \multicolumn{21}{|c|}{ First season } \\
\hline & & & & & & & & & & & & & & & & & & & & & \\
\hline Cultivar & Goya & Hama & Mean & Goya & Hama & Mean & Goya & Hama & Mean & Goya & Hama & Mean & Goya & Hama & Mean & Goya & Hama & Mean & Goya & Hama & Mean \\
\hline \multicolumn{22}{|l|}{ Water type } \\
\hline mag & $157 \mathrm{a}$ & $12 \mathrm{~b}$ & $14 \mathrm{~A}$ & $7.3 \mathrm{ab}$ & $7.7 \mathrm{a}$ & $7.5 \mathrm{~A}$ & $177.1 \mathrm{a}$ & $136.9 \mathrm{~b}$ & $157.00 \mathrm{~A}$ & $2125 \mathrm{a}$ & $1643 \mathrm{~b}$ & $1256 \mathrm{~A}$ & $28.35 \mathrm{a}$ & $25.19 \mathrm{~b}$ & $26.77 \mathrm{~A}$ & $96.0 \mathrm{a}$ & $91.3 \mathrm{~b}$ & $93.65 \mathrm{~A}$ & $2.17 \mathrm{~b}$ & $2.17 \mathrm{~b}$ & $2.17 \mathrm{~B}$ \\
\hline normal & $130 \mathrm{~b}$ & $99 \mathrm{c}$ & $114.5 B$ & $6.0 \mathrm{~b}$ & $6.0 \mathrm{~b}$ & $6.0 \mathrm{~B}$ & $142.5 \mathrm{~b}$ & $110.2 \mathrm{c}$ & $126.35 \mathrm{~B}$ & $1710 \mathrm{~b}$ & $1322 \mathrm{c}$ & $1011 \mathrm{~B}$ & $25.52 \mathrm{~b}$ & $21.93 \mathrm{c}$ & $23.73 \mathrm{~B}$ & $93.3 \mathrm{ab}$ & $90.0 \mathrm{~b}$ & $91.65 \mathrm{~A}$ & $2.41 \mathrm{a}$ & $2.32 \mathrm{ab}$ & $2.36 \mathrm{~A}$ \\
\hline Mean & $143.5 \mathrm{~A}$ & $113 \mathrm{~B}$ & & $6.65 \mathrm{~A}$ & $6.85 \mathrm{~A}$ & & $159.80 \mathrm{~A}$ & $123.55 \mathrm{~B}$ & & $1917 \mathrm{~A}$ & $1482 B$ & & $26.94 \mathrm{~A}$ & $23.56 \mathrm{~B}$ & & $94.65 \mathrm{~A}$ & $90.65 \mathrm{~B}$ & & $2.290 \mathrm{~A}$ & $2.245 \mathrm{~A}$ & \\
\hline & \multicolumn{21}{|c|}{ second season } \\
\hline Cultivar & Goya & Hama & Mean & Goya & Hama & Mean & Goya & Hama & Mean & Goya & Hama & Mean & Goya & Hama & Mean & Goya & Hama & Mean & Goya & Hama & Mean \\
\hline \multicolumn{22}{|l|}{ Water type } \\
\hline mag & $121 \mathrm{a}$ & $100 \mathrm{ab}$ & $110.5 \mathrm{a}$ & $6.2 \mathrm{ab}$ & $6.5 \mathrm{a}$ & $6.35 \mathrm{~A}$ & $136.6 \mathrm{a}$ & $107.7 \mathrm{~b}$ & $122.1 \mathrm{~A}$ & $1639 \mathrm{a}$ & $1292 \mathrm{~b}$ & $1465 \mathrm{~A}$ & $24.56 \mathrm{a}$ & $19.95 \mathrm{~b}$ & $22.26 \mathrm{~A}$ & $96.0 \mathrm{a}$ & $92.0 \mathrm{ab}$ & $94.00 \mathrm{~A}$ & $2.12 \mathrm{~b}$ & $2.06 \mathrm{c}$ & $2.09 \mathrm{~B}$ \\
\hline normal & $92 \mathrm{bc}$ & $71 \mathrm{c}$ & $81.5 \mathrm{~b}$ & $5.8 \mathrm{ab}$ & $5.7 \mathrm{~b}$ & $5.75 \mathrm{~B}$ & $100.9 \mathrm{bc}$ & $80.0 \mathrm{c}$ & $90.5 \mathrm{~B}$ & $1211 \mathrm{bc}$ & $960 \mathrm{c}$ & 1085B & $20.47 \mathrm{~b}$ & $17.86 \mathrm{c}$ & $19.17 \mathrm{~B}$ & $96.0 \mathrm{a}$ & $90.7 \mathrm{~b}$ & $93.35 \mathrm{~A}$ & $2.28 \mathrm{a}$ & $2.18 \mathrm{ab}$ & $2.23 \mathrm{~A}$ \\
\hline Mean & $106.5 \mathrm{~A}$ & $85.5 \mathrm{~B}$ & & $6.0 \mathrm{~A}$ & $6.1 \mathrm{~A}$ & & $118.8 \mathrm{~A}$ & $93.8 \mathrm{~B}$ & & $1425 \mathrm{~A}$ & $1126 \mathrm{~B}$ & & $22.52 \mathrm{~A}$ & $18.91 \mathrm{~B}$ & & $96.0 \mathrm{~A}$ & $91.35 \mathrm{~B}$ & & $2.20 \mathrm{~A}$ & $2.12 \mathrm{~A}$ & \\
\hline
\end{tabular}

Values followed by the same letter are not significantly different, using Duncan's multiple range test at $5 \%$ level. 


\section{REFERENCES}

1. A.O.A.C. 2000. Association of Official Analytical Chemists, Official Methods of Analysis. Washington. D.C., USA $17^{\text {th }}$ ed,

2. Abou El-Yazied A, El-Gizawy AM, Khalf SM, El-Satar A and Shalaby OA. 2012. Effect of magnetic field treatments for seeds and irrigation water as well as $\mathrm{N}$, $\mathrm{P}$ and $\mathrm{K}$ levels on productivity of tomato plants. Journal of Applied Sciences Research. 8 (4):2088-2099.

3. Al-Qaesi MR. 2009. Effect of magnetic irrigation water, chemical fertilizer and types of natural organic fertilizer on growth and yield of water melon growth in Gypsferous soil. Diyala Agricultural Sciences Journal. 1(2):124-133.

4. Bogoescu M. 2000. The water quality and irrigation method influence about the autumn white cabbage yield. Acta Horticulturae. (533):447-450.

5. Doria E, Campion B, Sparvoli F, Tava A and Nielsen E. 2012. Anti-nutrient components and metabolites with health implications in seeds of 10 common bean (Phaseolus vulgaris L. and Phaseolus lunatus L.) landraces cultivated in southern Italy. Journal of Food Composition and Analysis. 26(1-2): 72-80.

6. Duncan DB. 1955. Multiple range and multiple F. test. Biometrics 11:1-42.

7. El Sayed HEA. 2014. Impact of magnetic water irrigation for improve the growth, chemical composition and yield production of broad bean (Vicia faba L.) plant. American Journal of Experimental Agriculture. 4(4): 476-496.

8. Grewal HS and Maheshwari BL. 2011. Magnetic treatment of irrigation water and snow pea and chickpea seeds enhances early growth and nutrient contents of seedlings. Bioelectromagnetics. 32:58-65.

9. Hozayn M and Qados AMSA. 2010a. Irrigation with magnetized water enhances growth, chemical constituent and yield of chickpea (Cicer arietinum L.). Agriculture and Biology Journal of North America. 1(4):671-676.

10. Hozayn M and Qados AMSA. 2010b. Magnetic water application for improving wheat (Triticum aestivum L.) crop production. Agriculture and Biology Journal of North America. 1(4):677-682.

11. Hozayn M, Abdel-Monem AA, Abdul Qados AMS and Abd El-Hameed HM. 2011. Response of some food crops to irrigation with magnetized water under green house condition. Australian Journal of Basic and Applied Sciences. 5(12):2936.

12. Maheshwari BL and Grewal HS. 2009. Magnetic treatment of irrigation water: Its effects on vegetable crop yield and water productivity. Agricultural Water Management 96: 1229-1236. 
13. Mostafazadeh-Fard B, Khoshravesh M, Mousavi SF and Kiani AR. 2011. Effects of magnetized water and irrigation water salinity on soil moisture distribution in trickle irrigation. Journal of Irrigation and Drainage Engineering. 137(6):398-403.

14. Nasher SH. 2008. The effect of magnetic water on growth of chick-pea seeds. Eng. \& Tech. 26 (9).

15. Peilai H, Shaoou W, Jianying S, Wenxing S and Baoguo Z. 2004. Effect of irrigating with magnetized water on tomato. Acta Agriculturae Shanghai. 20(4):50-52.

16. Qados AMSA and Hozayn M. 2010. Magnetic water technology, a novel tool to increase growth, yield and chemical constituents of lentil (Lens esculenta) under greenhouse condition. American-Eurasian Journal of Agricultural and Environmental Science. 7(4):457-462.

17. Sadeghipour $O$ and Aghaei P. 2013. Improving the growth of cowpea (Vigna unguiculata L. Walp.) by magnetized water. Journal of Biodiversity and Environmental Sciences (JBES). 3(1):37-43.

18. Scaloppi EJ. 2008. Irrigation of horticultural crops with magnetized water. Central theme, technology for all: sharing the knowledge for development. Proceedings of the International Conference of Agricultural Engineering, XXXVII Brazilian Congress of Agricultural Engineering, International Livestock Environment Symposium - ILES VIII, Iguassu Falls City, Brazil, 31st August to 4th September. : unpaginated.

19. Selim AH, Zayed MAh and Zayed MAt. 2013. Magnetic field treated water effects on germination, growth and physio-chemical aspects of some economic plants. Acta Botanica Hungarica. 55(1/2):99-116.

20. Snedecor GW and Cochran WG. 1980. Statistical methods. $7^{\text {th }}$ edition, Iowa State University Press, Ames, Iowa. 


\section{المعالجة المغناطيسية لمياه الري لتحسين النمو الخضري والمحصول الطازج والجاف من الفاصوليا النامية بالصوب البلاستيكية}

إنتصار خطاب عبد الهادى خطاب، منى عبد الونيس محمد، أمل زكريا حجازى، عرفة إمام عرفة

$$
\text { معهُ بحوث البساتين - مركز البحوث الزراعية- الجيزة- مصر }
$$

إستخدام الماء الممغنط هو أحد العوامل البيئية الهامة فى الزراعة وخصوصاً في نظام الري

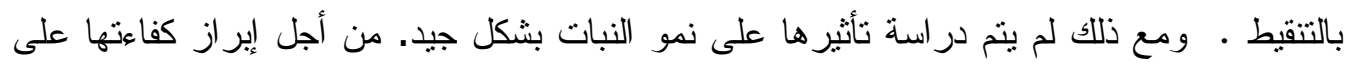

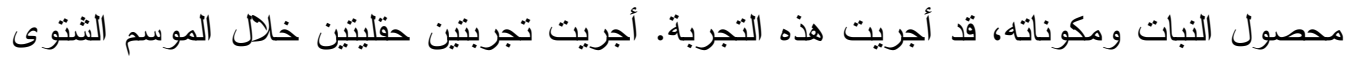

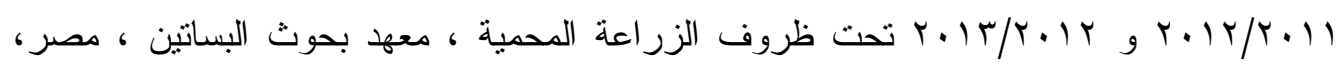

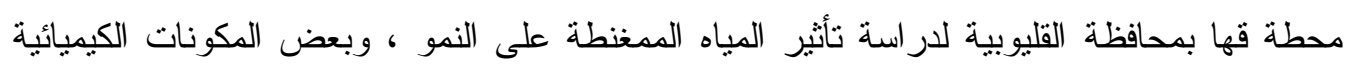

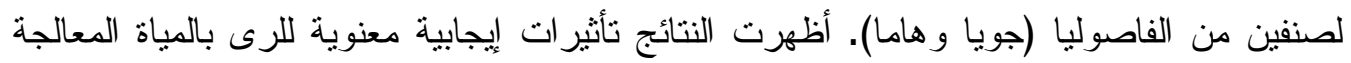

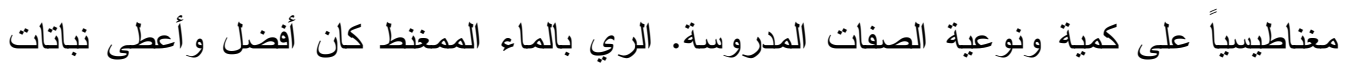

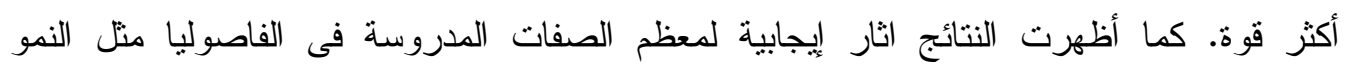
الخضري و المحصول الطازج و البذرى و محتوي الأوراق من NPK عند إستخدام المياه

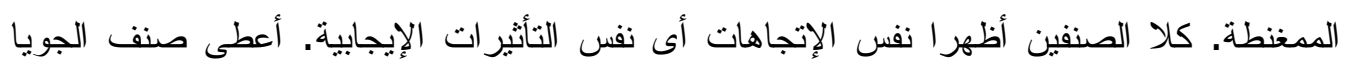
نتائج أفضل لكلٍ من المحصول الخضري (المبكر و الإجمالي والمحصول الطازج للنبات)

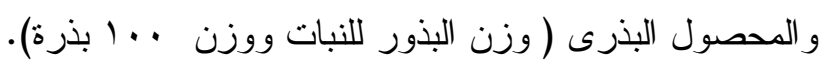

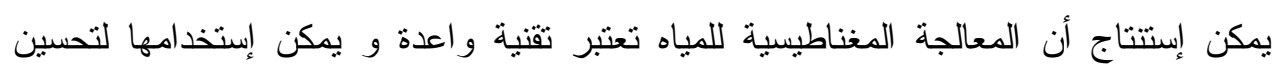
النمو، و المكونات الكيميائية و إنتاجية الفاصوليا تحت ظروف الزر اعة البلاستيكية. في حين أن نتائج هذه الدراسة مثيرة للإهتمام بالنسبة للزر اعة تحت الصوب، فإن إمكانات العلاج المغناطيسي لمياه الري لإنتاج المحاصيل يحتاج إلى مزيد من الدراسة في الزر اعات المكثوفة لتوضيح آثناره الإيجابية على إنتاجية الدحاصيل. 